\title{
НЕВІДВОРОТНІСТЬ ПЕРЕХОДУ УКРАЇНИ ДО ВІДНОВЛЮВАНОЇ ЕНЕРГЕТИКИ
}

Б.Г. Тучинський ${ }^{1}$, канд. екон. наук, ст. наук. співроб., С.О. Кудря ${ }^{1,2}$, чл.-кор. НАН України, докт. техн. наук, проф., І.В. Іванченко ${ }^{1}$, В.Ю. Іванчук ${ }^{1,2}$, студент

${ }^{1}$ Інститут відновлюваної енергетики НАН України, 02094, вул. Гната Хоткевича, 20А, м. Київ, Україна.

${ }^{2}$ Національний технічний університет України «Київський політехнічний інститут ім. Ігоря Сікорського», 03056, пр-т. Перемоги, 37, м. Київ, Україна.

В статті розглянуто суттєві проблеми сучасної української електроенергетики. Знотеність енергетичного обладнання TEC і АЕС перевищуе допустимі проектні ліміти, щзо зменшує стійкість постачання електроенергії споживачам, збільшує обсяги локальних $і$ глобальних шкідливих викидів, збільшуе питомі витрати палива на ТЕС $і$ АЕС, а з ичим - збільщуе собівартість і ціну продажу електроенергії. Ще одним з викликів для електроенергетики Украӥни є залежність від імпорту палива. Пріоритетний розвиток виробництва електроенергї з відновлюваних джерел енергії, обраний європейськими краӥнами, дозволив подолати проблеми фізичного і морального зносу обладнання, доступу до енергоносіїв, екологічної чистоти роботи електростанцій, ефективності виробнищтва електроенергії для інвесторів і для держави. Для України є дуже важливим ией позитивний європейський досвід подолання кризи в електроенергетииі.

За даними International Energy Agency в період 2014-2035 pр. інвестииії у відновлювані технології виробництва електроенергії в країнах ЄС перевищать інвестииії в галузі традиційної енергетики (ТЕС і АЕС) разом взяті, більше ніж у три рази.

Результати функціонування свропейської електроенергетики за новим “низьковуглещевим” курсом засвідчують, щзо стратегічні рішення в європейській електроенергетиці були вдалими - країни Європи подолали всі перешкоди розвитку. Зважсаючи на подібність багатьох нагальних проблем украйнської і європейської електроенергетики, а також на значний енергетичний потенціал відновлюваних джерел енергї України, зокрема енергії сонця та вітру - 2273 млрд кВт.год у рік, стратегічні рішення для украӥнської електроенергетики мають враховувати відповідний європейський досвід пріоритетного розвитку виробництва електроенергії з відновлюваних джерел енергії. Крім того, проведений аналіз дає обтрунтований висновок, щчо відновлювані технології виробництва електроенергії найбільш привабливі для інвесторів.

Бібл. 19, табл. 8, рис. 12.

Ключові слова: електроенергетика, електроенергетичне обладнання, енергоносії, екстернальні витрати, ефективність, відновлювана енергетика.

\section{INEVITABILITY OF UKRAINE'S TRANSITION TO RENEWABLE ENERGY}

B. Tuchynskyi ${ }^{1}$, candidate of economic sciences, senior researcher, S. Kudrya ${ }^{\mathbf{1}, \mathbf{2}}$, corresponding member of NAS, doctor of technical sciences, professor, I. Ivanchenko ${ }^{\mathbf{1}}$, V. Ivanchuk ${ }^{\mathbf{1}, \mathbf{2}}$, student

${ }^{1}$ Institute of Renewable Energy of the National Academy of Sciences of Ukraine, 02094, 20A Hnata Khotkevycha St., Kyiv, Ukraine.

${ }^{1,2}$ National Technical University of Ukraine «Igor Sikorsky Kyiv Polytechnic Institute», 03056, 37 Peremohy Av., Kyiv, Ukraine.

The article considers significant problems of modern Ukrainian electric power industry. Depreciation of TPP and NPP energy equipment exceeds the allowable design limits, which reduces the sustainability of electricity supply to consumers, increases local and global harmful emissions, increases specific fuel consumption at TPPs and NPPs, and thus increases the cost and price of electricity sales. Another challenge for Ukraine's electricity sector is its dependence on fuel imports. The priority development of electricity production from renewable energy sources, chosen by European countries, has overcome the problems of physical and moral wear of equipment, access to energy, environmental cleanliness of power plants, efficiency of electricity production for investors and the state. This positive European experience of overcoming the electricity crisis is very important for Ukraine.

According to the International Energy Agency, in the period 2014-2035, investments in renewable electricity generation technologies in the $E U$ will exceed investments in the field of traditional energy (TPP and NPP) combined, more than three times.

The results of the operation of the European electricity sector at the new "low-carbon" rate show that the strategic decisions in the European electricity sector were successful - European countries overcame all obstacles to development.

Given the similarity of many pressing problems of Ukrainian and European electricity, as well as the significant energy potential of renewable energy sources in Ukraine, including solar and wind energy - 2273 billion $k$ Wh per year, strategic decisions for Ukrainian electricity should take into account relevant European experience of priority electricity production from renewable energy sources. In addition, the analysis gives a reasonable conclusion that renewable electricity generation technologies are the most attractive for investors. Ref. 19, tables 8, fig. 12.

Keywords: electric power, electric power equipment, energy fuels, external costs, efficiency, renewable energy. 


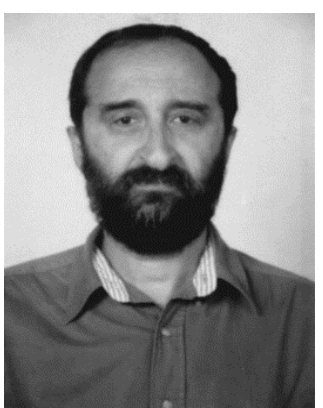

Б.Г. Тучинський B. Tuchynskyi

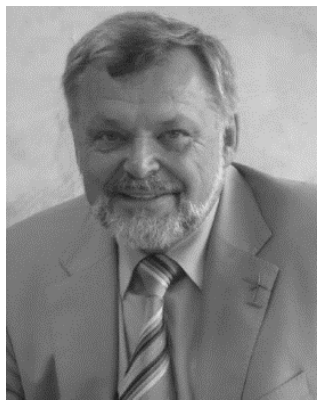

C.O. Кудря S. Kudria

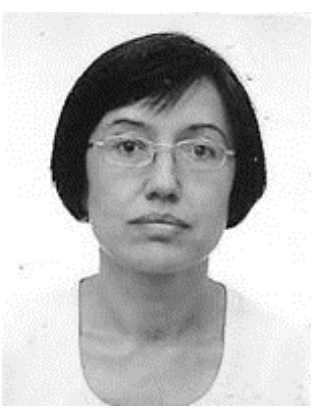

I.В. Іванченко I. Ivanchenko

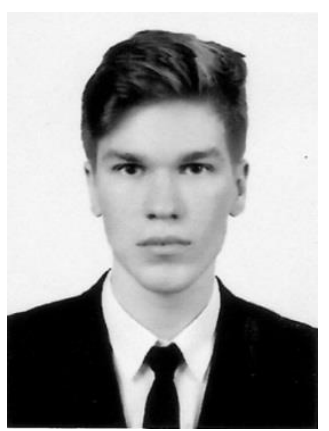

В.Ю. Іванчук V. Ivanchuk
Відомості про автора: старший науковий співробітник відділу вітроенергетики Інституту відновлюваної енергетики НАН України, старший науковий співробітник, кандидат економічних наук.

Освіта: Київський національний університет ім. Тараса Шевченка, механіко-математичний факультет.

Наукова сфера: прикладна математика, обчислювальні методи в математиці, математична статистика, математичні моделі і методи в економіці, інвестиційний аналіз, вітроенергетика.

Публікації: 117

ORCID: 0000-0002-5180-6886

Контакти: тел./факс: +38(044)206-28-09 e-mail: bortu77@yahoo.com

Відомості про автора: директор Інституту відновлюваної енергетики НАН України, член-кореспондент НАН України, професор, доктор технічних наук.

Освіта: Національний технічний університет України «Київський політехнічний інститут ім. І. Сікорського», хіміко-технологічний факультет.

Наукова сфера: відновлювані джерела енергії, акумулювання енергії, енергоефективні технології, воднева енергетика.

Публікації: 370

ORCID: 0000-0002-4798-6853

Контакти: тел./факс: +38(044)206-28-09 e-mail: renewable@ukr.net

Відомості про автора: головний технолог відділу вітроенергетики Інституту відновлюваної енергетики НАН України. Освіта: Київський національний університет технологій та дизайну, інженерноекономічний факультет.

Область наукових інтересів:

вітроенергетика, оцінка вітроенергетичного потенціалу, економічна ефективність інвестицій в будівництво вітрових електростанцій.

Публікації: 30 .

ORCID: 0000-0002-5083-4180

Контакти: тел./факс: +38(044)206-28-09

e-mail: mntcwind@gmail.com

Відомості про автора: провідний інженер відділу №1 Комплексних енергосистем Інституту відновлюваної енергетики НАН України, студент Національного технічного університету України «Київський політехнічний інститут імені Ігоря Сікорського».

Освіта: студент 6-го курсу кафедри відновлюваних джерел енергії факультету електроенерготехніки та автоматики Національного технічного університету України «Київський політехнічний інститут імені Ігоря Сікорського».

Наукова сфера: відновлювана енергетика. Публікації: 14.

ORCID: 0000-0002-0585-9610

Контакти: +38(096)533-03-86

e-mail: vladdos.iv98@gmail.com
Author information: senior researcher at wind energy department at Institute of Renewable Energy of NAS of Ukraine, senior researcher, candidate of economic sciences.

Education: Taras Shevchenko National

University of Kyiv, Faculty of Mechanics and Mathematics.

Research area: applied mathematics, computational methods in mathematics, mathematical statistics, mathematical models and methods in economics, investment analysis, wind power.

Publications: 117.

ORCID: 0000-0002-5180-6886

Contacts: tel./fax: +38(044)206-28-09

e-mail: bortu77@yahoo.com

Author information: director of the Institute of Renewable Energy of NAS of Ukraine,

Corresponding Member of NAS of Ukraine, professor, doctor of technical sciences.

Education: National Technical University of Ukraine "Igor Sikorsky Kyiv Polytechnic Institute", Faculty of Chemical Technology. Research area: renewable energy sources, energy storage, energy efficient technologies, hydrogen energy.

Publications: 370 .

ORCID: 0000-0002-4798-6853

Contacts: tel./fax: +38(044)206-28-09

e-mail: renewable@ukr.net

Author information: chief technologist at wind energy department at Institute of Renewable Energy of NAS of Ukraine.

Education: Kiev National University of Technology and Design, Faculty of Engineering and Economics.

Main research interests: wind energy,

assessment of wind energy potential, economic efficiency of investments in the construction of wind power plants.

Publications: 30 .

ORCID: 0000-0002-5083-4180

Contacts: tel./fax: +38(044)206-28-09

e-mail: mntcwind@gmail.com

Author information: Leading engineer of Department №1 of Complex Power Systems of the Institute of Renewable Energy of the NAS of Ukraine, student of the National Technical University of Ukraine "Igor Sikorsky Kyiv Polytechnic Institute".

Education: student of 6th course of the Department Renewable Energy Sources of Faculty of Electric Power Engineering and Automatics of the National Technical University of Ukraine "Igor Sikorsky Kyiv Polytechnic Institute".

Research area: renewable energy.

Publications: 14.

ORCID: 0000-0002-0585-9610

Contacts: +38(096)533-03-86

e-mail: vladdos.iv98@gmail.com 
Перелік використаних позначень та скорочень:

$\begin{array}{ll}\text { АЕС - атомна електрична станція; } & \text { СЕС - сонячна електрична станція; } \\ \text { ВДЕ - відновлювані джерела енергії; } & \text { ТЕС - теплова електрична станція; } \\ \text { ВЕС - вітрова електрична станція; } & \text { LCOE - levelized cost of energy; } \\ \text { ГЕС - гідроелектрична станція; } & \text { NPP - nuclear power plant; } \\ \text { EC - електрична станція; } & \text { TPP - thermal power plant; } \\ \text { ЄС - Свропейський Союз; } & \text { WNA - World Nuclear Association; } \\ \text { КВВП - коефіцієнт використання встановленої } & \text { МВТ - мегават; } \\ \text { потужності; } & \text { кВТ - кіловат; } \\ \text { НЕК - Національна енергетична компанія; } & \text { кВт·год - кіловат-година. }\end{array}$

ПСЕ - продовження строку експлуатації;

Вступ. Після розпаду СРСР Україна Оскільки мілітаризація була основним завданням отримала від нього потужний комплекс по радянської держави, для ії розвитку в Україні було виробництву військово-промислової продукції, створено потужний i розгалужений електроенергоємність якої була однією з найвищих в світі. енергетичний комплекс (рис. 1 [1]).

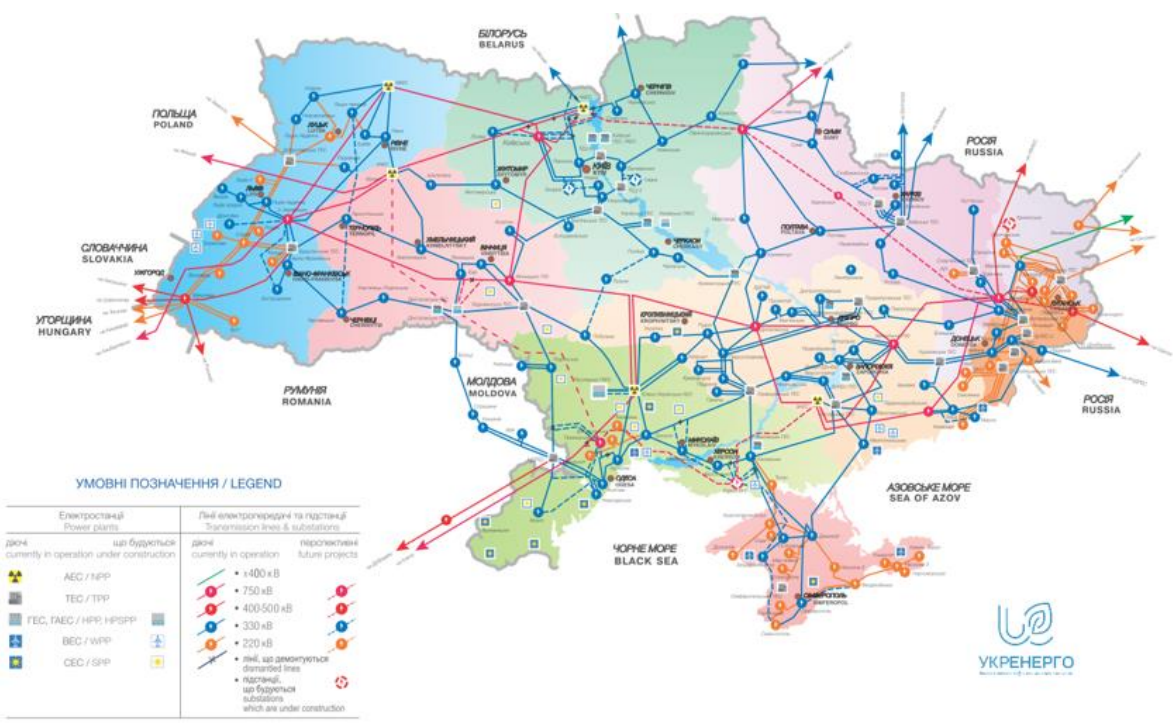

Рис. 1. Карта електроенергетики України (2016 р.).

Fig. 1. Map of Ukraine's electric power industry (2016).

На рис. 2-3 представлено карти виробництва і споживання електроенергії по областях України.

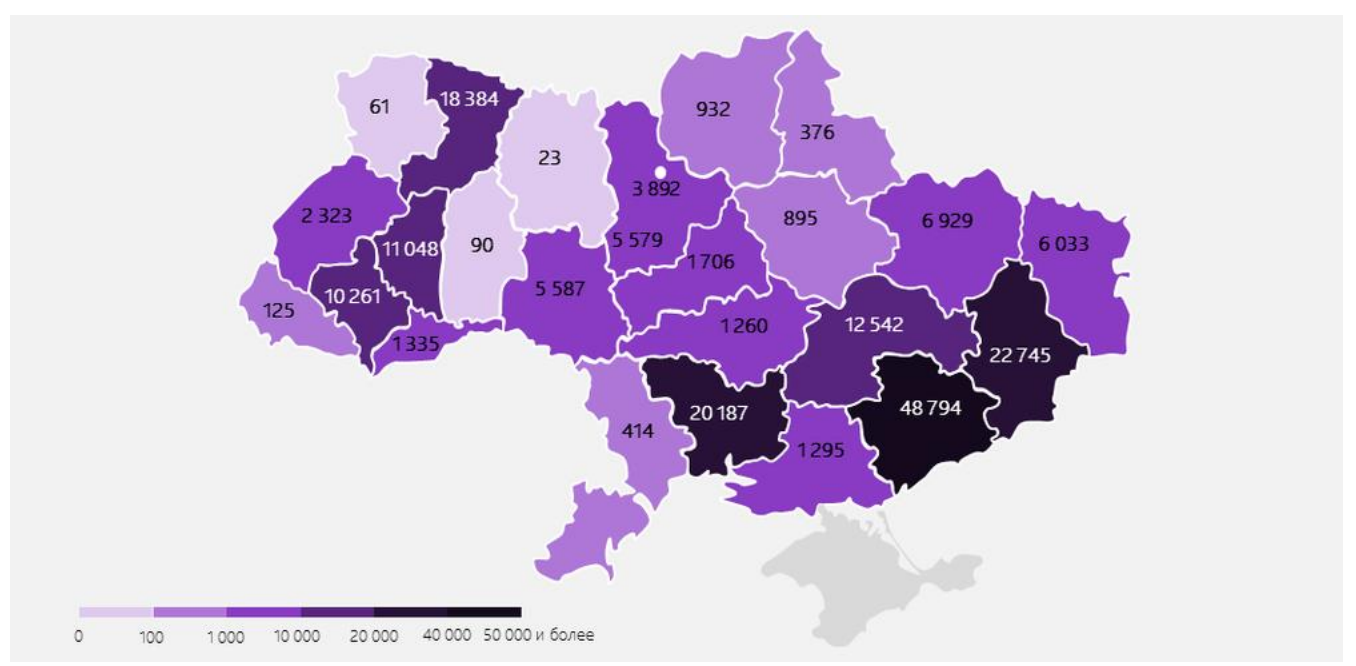

Рис. 2. Карта виробництва електроенергії по областях України (2014р.) в млн кВт•год [2].

Fig. 2. Map of Ukraine's electricity production by regions (2014) in million $\mathrm{kWh}$ [2]. 


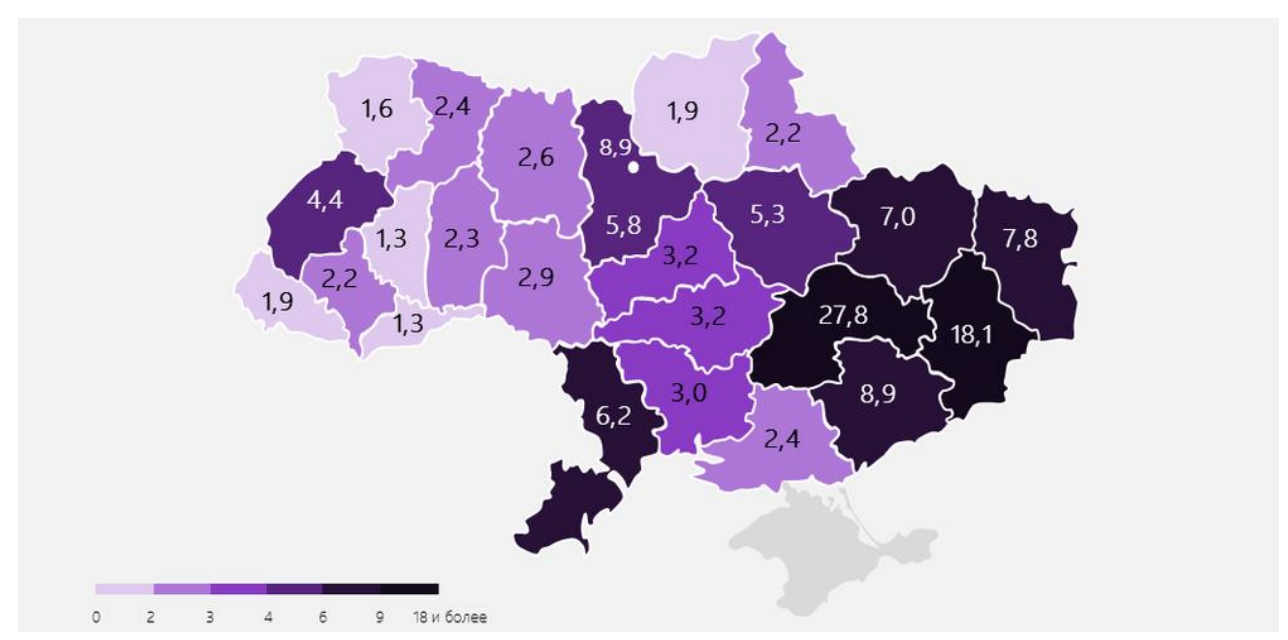

Рис. 3. Карта споживання електроенергії по областях України (2014 р.) в млрд кВт·год [2].

Fig. 3. Map of Ukraine's electricity consumption by regions (2014) in billion kWh [2].

3 рис. 2-3 видно, що в Дніпропетровській, Одеській, Херсонській, Луганській та деяких інших областях власного виробництва електроенергії не вистачає для задоволення потреб споживачів. Тому певні об'єми електроенергії транспортуються в ці регіони іноді

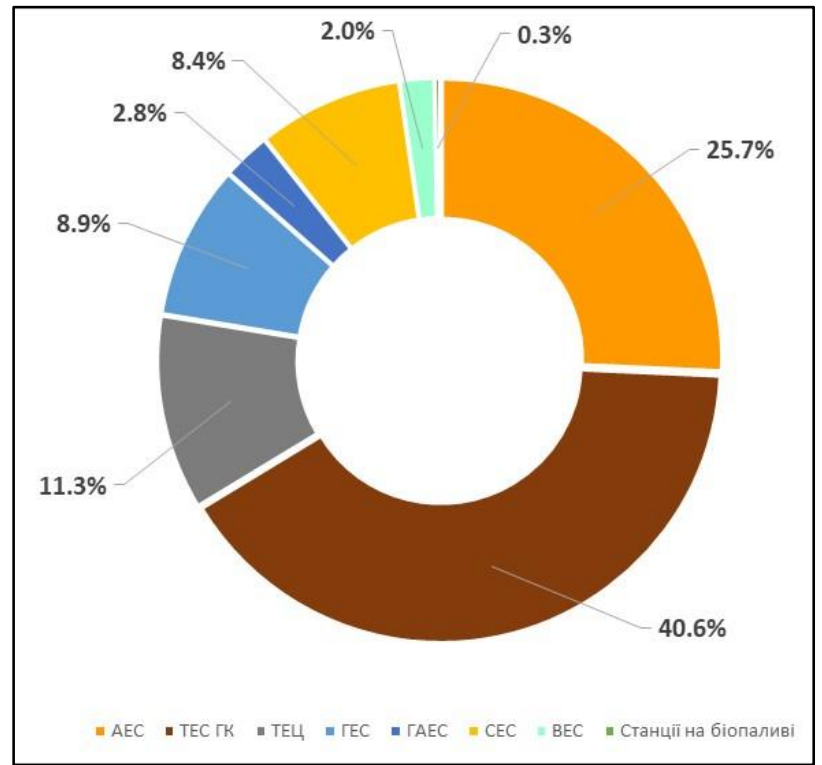

Рис. 4. Технологічна структура встановленої потужності електроенергетики України станом на 31.05.2020.

Fig. 4. Technological structure of the installed capacity of the electric power industry of Ukraine as of 31.05.2020.

Чи здатні українські AEC і TEC сьогодні і в перспективі забезпечити стійке покриття попиту на електроенергію у населення i підприємств України? Відповідь на це питання залежить від: обладнання; з віддалених від них електростанцій, що збільшує втрати електроенергії в процесі її передачі.

На рис. 4-5 представлено технологічну структуру електроенергетики України (підготовлено авторами за даними НЕК «Укренерго» [3]).

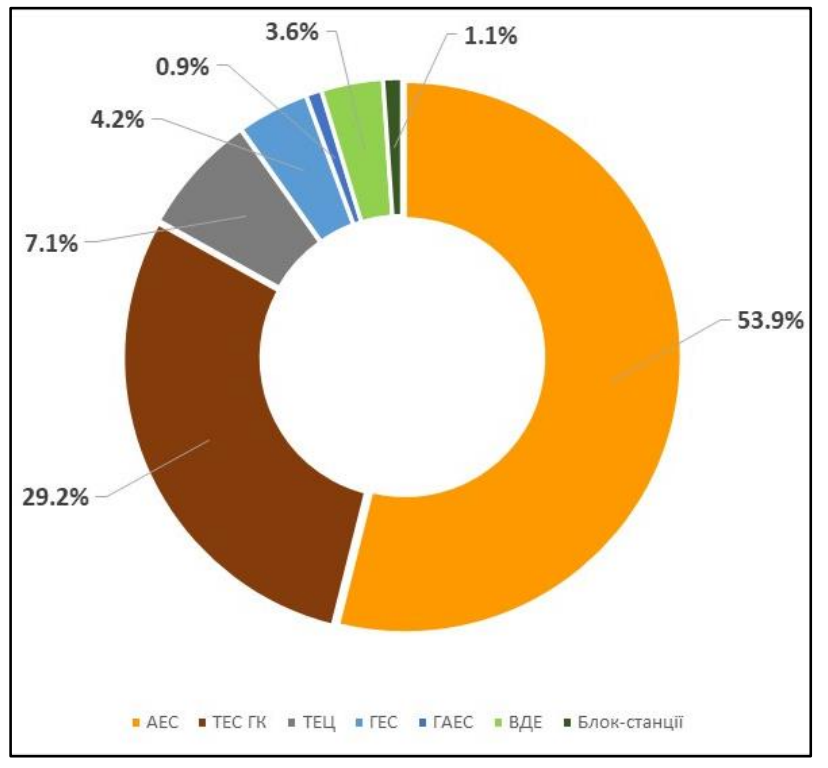

Рис. 5. Технологічна структура виробництва електроенергії в Україні станом на 31.12.2019.

Fig. 5. Technological structure of electricity production in Ukraine as of 31.12.2019.

- стійкості доступу до енергоносіїв;

- екологічної чистоти роботи електростанцій;

- ефективності виробництва електроенергії для інвесторів і для української держави. 
Щодо всіх цих чинників сучасна українська електроенергетика має суттєві проблеми, розглянуті нижче.

Електроенергетичне обладнання. В табл. 1 подано дані про знос обладнання українських ТЕС (підготовлено авторами за даними НЕК «Укренерго» [4]). 3 цієї таблиці наочно видно, що всі ТЕС України перевищили свій 40-річний проектний термін експлуатації. Дев'ять ТЕС перевищили термін 50 років експлуатації - всі вони потребують невідкладного оновлення обладнання.

Таблиця 1. Рівень зносу обладнання ТЕС.

Table 1. The level of wear of TPP equipment.

\begin{tabular}{|c|c|c|c|c|c|}
\hline № & Назва & $\begin{array}{c}\text { Потужність, } \\
\text { МВт }\end{array}$ & $\begin{array}{c}\text { Термін } \\
\text { введення в } \\
\text { експлуатацію } \\
\text { першого блоку } \\
\end{array}$ & $\begin{array}{c}\text { Рівень зносу } \\
\text { обладнання ТЕС }, \\
\text { років }\end{array}$ & $\begin{array}{c}\text { Проектний } \\
\text { термін } \\
\text { експлуатації, } \\
\text { років } \\
\end{array}$ \\
\hline 1 & Бурштинська & 2351 & 1965 & $>50$ & \multirow{14}{*}{$\begin{array}{l}40 \text { років для котлів } \\
\text { і турбін (згідно } \\
\text { міждержавного } \\
\text { стандарту 533- } \\
2000, \text { п. } 4.39, \\
\text { табл. } 2 \text { ) }\end{array}$} \\
\hline 2 & Вуглегірська & 3600 & 1972 & $>40$ & \\
\hline 3 & Добротвірська & 510 & 1960 & 60 & \\
\hline 4 & Запорізька & 3650 & 1972 & $>40$ & \\
\hline 5 & Зміївська & 2265 & 1961 & $>50$ & \\
\hline 6 & Зуївська & 1245 & 1980 & 40 & \\
\hline 7 & Криворізька & 2892 & 1965 & $>50$ & \\
\hline 8 & Курахівська & 1532 & 1972 & $>\mathbf{4 0}$ & \\
\hline 9 & Ладижинська & 1800 & 1970 & 50 & \\
\hline 10 & Луганська & 1495 & 1962 & $>50$ & \\
\hline 11 & Придніпровська & 1765 & 1959 & $>60$ & \\
\hline 12 & Слов'янська & 880 & 1971 & $>40$ & \\
\hline 13 & Старобешивська & 2000 & 1961 & $>50$ & \\
\hline 14 & Трипільська & 1825 & 1969 & $>50$ & \\
\hline
\end{tabular}

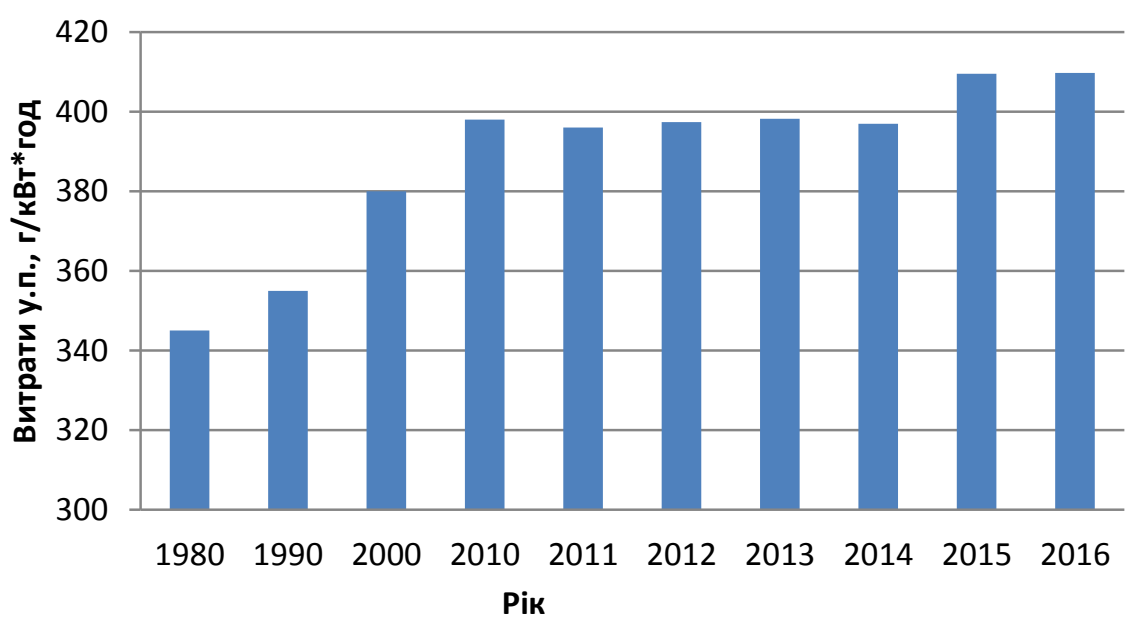

Рис. 6. Динаміка питомих витрат енергоносіїв на вугільних ТЕС України.

(Підготовлено авторами за даними 1980-2010 рp. -[5]; 2011-2016 рр. -ДТЕК).

Fig. 6. Dynamics of specific consumption of energy carriers at coal-fired TPPs in Ukraine.

(Prepared by the authors according to the data of 1980-2010 - [5]; 2011-2016-DTEK).

Негативними наслідками наднормативного зносу обладнання ТЕС є:

- збільшення питомих витрат енергоносіїв (рис. 6);

- зменшення продуктивності виробництва електроенергіі;
- зростання кількості масштабних аварій 3 порушенням стабільності роботи енергосистеми i відключеннями споживачів електроенергії;

- зростання ймовірності глобальних катастроф.

Подібна ситуація має місце і 3 атомними електростанціями (АЕС) - табл. 2. 
Таблиця 2. Терміни виводу з експлуатації енергоблоків АЕС [4].

Table 2. Terms of decommissioning of NPP power units [4].

\begin{tabular}{|c|c|c|c|c|c|c|}
\hline $\begin{array}{l}\text { Електрична } \\
\text { станція }\end{array}$ & $\begin{array}{c}\text { № } \\
\text { енерго } \\
\text {-блока }\end{array}$ & $\begin{array}{c}\text { Електрична } \\
\text { потужність, } \\
\text { МВт }\end{array}$ & $\begin{array}{c}\text { Тип } \\
\text { реакторної } \\
\text { установки }\end{array}$ & $\begin{array}{c}\text { Дата } \\
\text { введення в } \\
\text { експлуата- } \\
\text { цію }\end{array}$ & $\begin{array}{c}\text { Проектна дата } \\
\text { закінчення } \\
\text { терміну } \\
\text { експлуатації }\end{array}$ & $\begin{array}{c}\text { Стан виконання } \\
\text { робіт з ПСЕ } \\
\text { енергоблоків }\end{array}$ \\
\hline \multirow{4}{*}{$\begin{array}{c}\text { Рівненська } \\
\text { AEC }\end{array}$} & 1 & 420 & B-213 & 22.12 .1980 & 22.12 .2010 & $\begin{array}{c}\text { Tермін } \\
\text { експлуатацій } \\
\text { продовжено до } \\
22.12 .2030 \\
\end{array}$ \\
\hline & 2 & 415 & B-213 & 22.12 .1981 & 22.12 .2011 & $\begin{array}{c}\text { Термін } \\
\text { експлуатацї̈ } \\
\text { продовжено } \\
\text { до 22.12.2031 } \\
\end{array}$ \\
\hline & 3 & 1000 & B-320 & 21.12.1986 & 11.12 .2017 & Виконуються \\
\hline & 4 & 1000 & B-320 & 10.10 .2004 & 07.06 .2035 & Плануються \\
\hline \multirow{3}{*}{$\begin{array}{l}\text { Южно- } \\
\text { Українська } \\
\text { AEC }\end{array}$} & 1 & 1000 & B-302 & 31.12 .1982 & 02.12 .2013 & $\begin{array}{c}\text { Термін } \\
\text { експлуатаціі } \\
\text { продовжено } \\
\text { до 02.12.2023 } \\
\end{array}$ \\
\hline & 2 & 1000 & B-338 & 09.01 .1985 & 12.05 .2015 & $\begin{array}{c}\text { Термін } \\
\text { експлуатаціі } \\
\text { продовжено } \\
\text { до } 31.12 .2025 \\
\end{array}$ \\
\hline & 3 & 1000 & B-320 & 20.09 .1989 & 10.02 .2020 & Виконуються \\
\hline \multirow{6}{*}{$\begin{array}{c}\text { 3апорізька } \\
\text { AEC }\end{array}$} & 1 & 1000 & B-320 & 10.12 .1984 & 23.12 .2015 & $\begin{array}{c}\text { Термін } \\
\text { експлуатаціі } \\
\text { продовжено } \\
\text { до 23.12.2025 } \\
\end{array}$ \\
\hline & 2 & 1000 & B-320 & 22.07 .1985 & 19.02 .2015 & $\begin{array}{c}\text { Термін } \\
\text { експлуатацї } \\
\text { продовжено } \\
\text { до 19.02.2025 } \\
\end{array}$ \\
\hline & 3 & 1000 & B-320 & 10.12.1986 & 05.03 .2017 & Виконуються \\
\hline & 4 & 1000 & $B-320$ & 18.12.1987 & 04.04 .2018 & Виконуються \\
\hline & 5 & 1000 & B-320 & 14.08.1989 & 27.05 .2020 & Плануються \\
\hline & 6 & 1000 & $B-320$ & 19.10.1995 & 21.10 .2026 & Плануються \\
\hline \multirow{2}{*}{$\begin{array}{c}\text { Хмельницька } \\
\text { AEC }\end{array}$} & 1 & 1000 & B-320 & 22.12 .1987 & 13.12 .2018 & Плануються \\
\hline & 2 & 1000 & B-320 & 07.08 .2004 & 07.09 .2035 & Плануються \\
\hline
\end{tabular}

В проектах цих AEC закладено граничний термін їх експлуатації 30 років. Наразі цей термін подовжено ще на 10 років та на 20 років (Рівненська АЕС). На рис. 7 подано побудовану за даними табл. 2 діаграму частки потужності блоків українських AEC, що не перевищили тридцятирічний термін експлуатації.

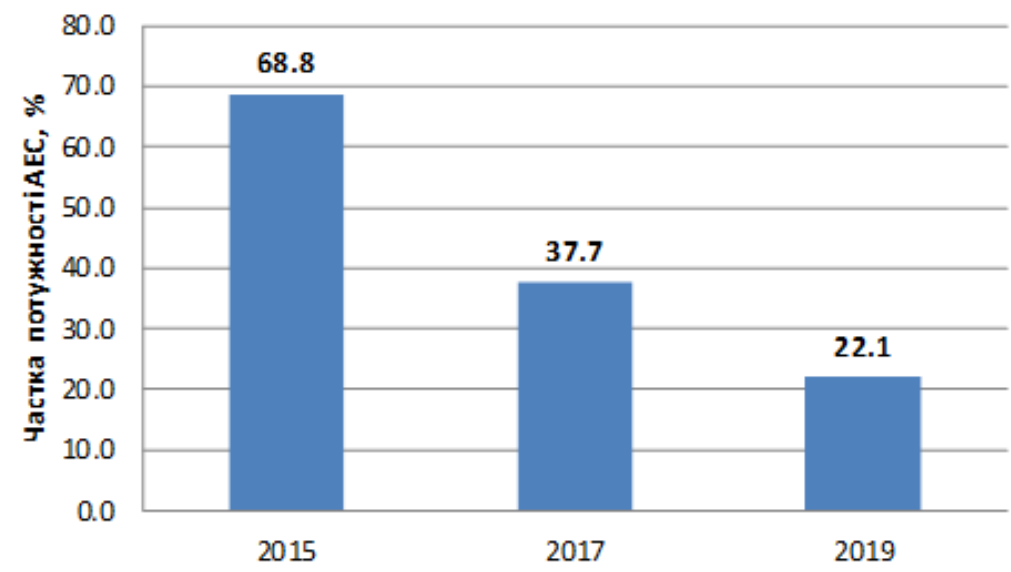

Рис. 7. Динаміка частки потужності блоків АЕС, що не перевищили тридцятирічний термін експлуатації.

Fig. 7. Dynamics of the share of NPP units that did not exceed thirty years of operation.

3 діаграми на рис. 7 видно, що в 2019 році потужність діючих блоків АEC, що функціонували в режимі надлімітної експлуатації, становила $78 \%$.

Кожен рік надлімітної експлуатації АЕС:
- збільшує кількість і терміни простоїв блоків $\mathrm{AEC}$, що спричиняє перебої в постачанні електроенергії;

- збільшує ризики масштабних катастроф, в тому числі глобального характеру.

Ретельність і якість виконання досліджень і робіт, необхідних для подовження терміну 
експлуатації українських АЕС, мають відповідати діючим міжнародним стандартам.

Таким чином, зрозуміло, що українська електроенергетика потребує невідкладної реновації іï обладнання. Подальше зволікання 3 вирішенням цієї проблеми призводить до суттєвого: зниження продуктивності виробництва електроенергіі, підвищення ризиків енергетичних i техногенних катастроф, збільшення викидів в повітря речовин, шкідливих для здоров’я людей і для довкілля.

Серед нових проблем - вразливість енергоблоків AEC терористичним атакам i стихійним лихам. За даними Росатома [6], додаткова вартість відповідних систем безпеки становить біля 40 \% вартості енергоблока.

Енергоносії. Другою складовою, необхідною для функціонування електростанцій, $\epsilon$ енергоносії.

Енергоносіями електростанцій традиційного типу $\epsilon$ :

- вода, що тече - для ГЕС;

- природній газ і вугілля - для ТЕС;

- ядерне паливо - для АЕС.

На жаль, ситуація 3 енергоресурсами традиційних типів в Україні надзвичайно складна.

Водні ресурси, придатні для великих ГЕС, в Україні вже вичерпано.

В Україні газу і вугілля власного видобутку не вистачає для роботи ТЕС. За даними Українського інституту майбутнього, Україна імпортує $32 \%$ споживаного газу і $20 \%$ споживаного енергетичного вугілля. Весь імпортований газ постачається 3 Європи достатньо стабільно. Майже все імпортне вугілля на ТЕС постачається 3 Росії (90\% імпорту вугілля).

Щодо енергоносіїв для АЕС (ядерних паливних елементів), то їх імпорт складає 100 \% (3 них не менше $60 \% 3$ Росіі). I якщо російські поставки вугілля можна без суттєвих проблем диверсифікувати, то здійснити аналогічний захід для поставок ядерних паливних елементів дуже складно. Справа у тому, що всі без винятку реактори українських АЕС сконструйовано i вироблено в Росії, яка не має намірів поступатись ринком паливних елементів для цих реакторів. Тому росіяни утаємничують детальну інформацію про параметри функціонування реакторів і вимоги до параметрів паливних елементів. За таких умов дуже складно досягти високого рівня сумісності ядерних паливних елементів неросійського виробництва 3 російськими реакторами українських АЕС.

Така ситуація наражає Україну на високі ризики енергетичної катастрофи (враховуючи, що АЕС виробляють половину електроенергії рис. 5).

Екологія. В Україні склалась вкрай складна екологічна ситуація (рис. 8).

3 карти на рис. 8 видно, що великі площі території країни $є$ надзвичайно забрудненими i перебувають на межі екологічної катастрофи.

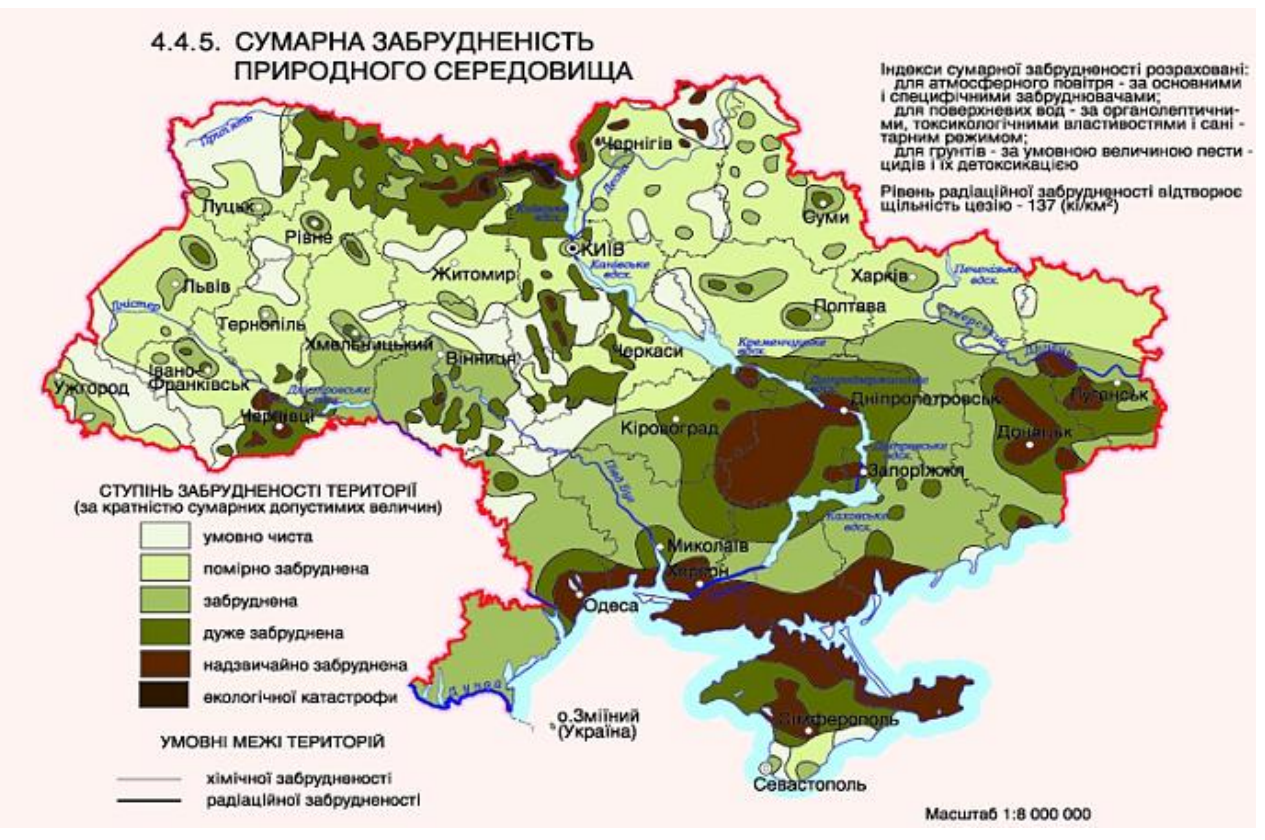

Рис. 8. Карта сумарної забрудненості природного середовища України [7].

Fig. 8. Map of total environmental pollution of Ukraine [7]. 
Вступ України до Енергетичного Співтовариства і Підписання Угоди про асоціацію з СС докорінно змінили ставлення енергетиків до проблем впливів електростанцій на довкілля [8]. Найбільш складна ситуація в цьому плані складається для ТЕС, що працюють на вугіллі.
Спалювання вугілля супроводжується значними обсягами локальних викидів речовин, дуже шкідливих для здоров'я людей і для довкілля. 3 рис. 9 видно, що шкідливі викиди ТЕС в Україні в рази перевищують нормативи $С$.
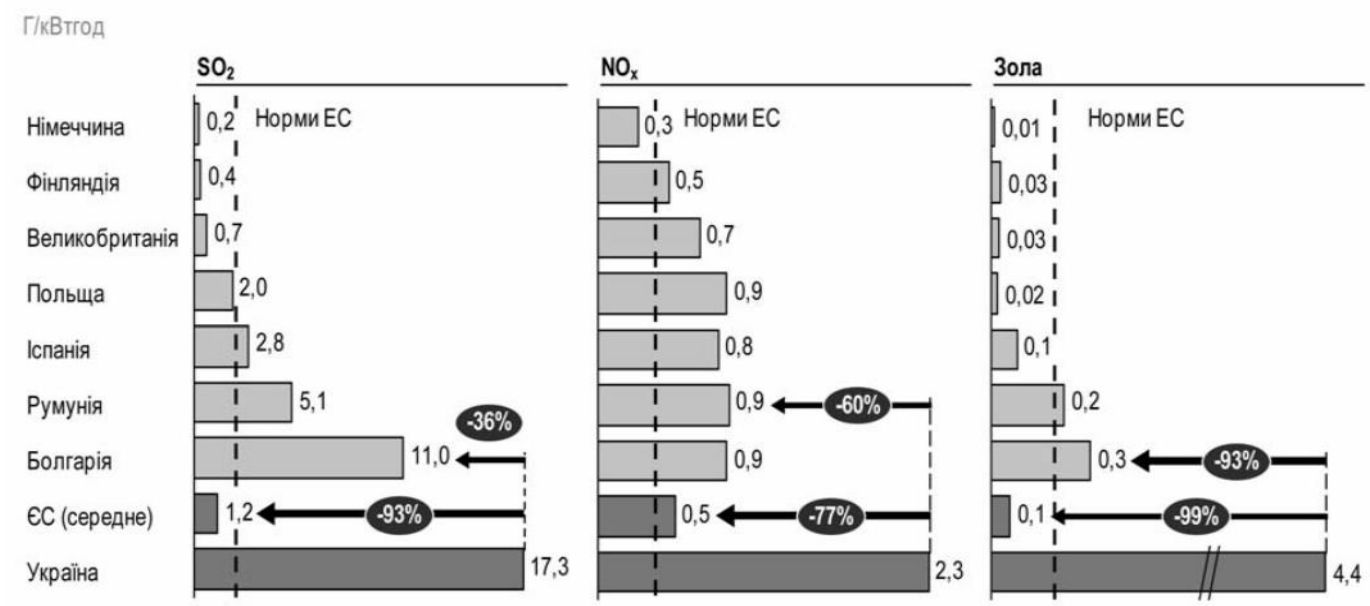

Рис. 9. Питомі викиди забруднюючих речовин ТЕС на вугіллі в Україні і деяких країнах Європи [5].

Fig. 9. Specific emissions of pollutants from coal-fired power plants in Ukraine and some European countries [5].

Крім того, ТЕС на вугіллі $є$ найбільш (Україна серед них), які підписали "Кіотський потужними емітентами глобальних викидів протокол до Рамкової Конвенції ООН про зміну парникових газів (рис. 10), контроль над якими клімату" (1997 р.) і Паризьку кліматичну угоду здійснюе міжнародне співтовариство країн (2015р.).

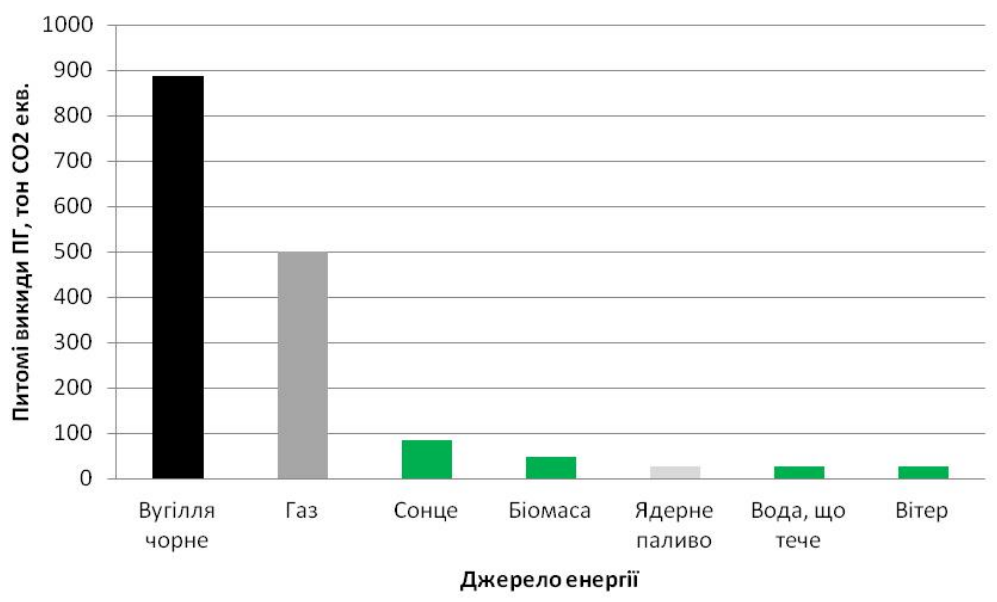

Рис. 10. Питомі викиди парникових газів у повному циклі перетворювання в електроенергію різних первісних джерел енергії. (Підготовлено авторами за даними WNA [9]).

Fig. 10. Specific greenhouse gas emissions in the full cycle of conversion into electricity of various primary energy sources.

(Prepared by the authors according to WNA [9]).

Стосовно екологічності атомної енергетики, то тут найбільші ризики виникають через неможливість усунути людський фактор в керуванні роботою АЕС, небезпеку тероризму і екстремальних погодних явищ. Причинами радіаційного забруднення атмосфери $є$ також процеси видобування і транспортування урану, транспортування i перевантаження напівфабрикатів і готових паливних елементів, а також радіоактивних відходів. Усвідомлення цих 
проблем, разом з пам'яттю про чорнобильську трагедію, сформувало негативне ставлення української громадськості до розвитку атомної енергетики.

В Україні водопостачання стає все більш гострою проблемою. Вже сьогодні Україна відноситься до країн з дефіцитом води. Технології ж виробництва електроенергії на TEC і AEC $є$ надто водомісткими. Так, виробництво 1 кВт·год електроенергії потребує води: на ТЕС - 1.9 літра, на AEC - 2.3 літра. В той же час, 3 такою ж метою витрачається води: на ВЕС - 0.004 літра (за даними [10]).

Ефективність. Як зазначалось, сучасні ТЕС на вугіллі потребують впровадження екологічно чистих технологій спалювання вугілля, що підвищує в 2-3 рази питомі інвестиції в цю технологію виробництва електроенергії.

AEC мають найвищі питомі інвестиції з усіх технологій виробництва електроенергії. Одною 3 суттєвих складових цих інвестицій є забезпечення ліквідації (декомісії) АЕС. Вартість відповідних робіт становить $1300-1400 \quad \$ / \kappa В$ т, термін виконання декомісії АЕC потужністю 10001200 МВт становить 20-25 років [11].

Статистика свідчить, що період 3 моменту вкладання інвестицій в будівництво блоку сучасної електростанції до отримання електроенергії становить: п'ять років і більше для TEC, i до 10 років (іноді - більше) для АЕС [12]. Централізоване виробництво електроенергії на потужних ТEC і АЕС, віддалене від споживачів електроенергії, потребує додаткових суттєвих інвестицій в будівництво ліній передач.

Вартість органічних енергоносіїв в світі постійно зростає по мірі вичерпання їх покладів. Особливо це стосується природного газу. Також зростає i вартість урану (а його власного видобутку для українських АЕС недостатньо), i відповідно вартість ядерного палива для АЕС.

В табл. 3 представлено витрати на виробництво електроенергії різними технологіями за даними Lazard [13].

Таблиця 3. Структура витрат на виробництво електроенергії різними технологіями.

Table 3. The cost structure of electricity generation by different technologies.

\begin{tabular}{|c|c|c|c|c|c|c|}
\hline Показник & $\begin{array}{l}\text { Од. } \\
\text { вим. }\end{array}$ & $\begin{array}{c}\text { ВEC } \\
\text { наземні }\end{array}$ & CEC & AEC & $\begin{array}{c}\text { ТЕС } \\
\text { на } \\
\text { вугіллі }\end{array}$ & $\begin{array}{c}\text { Пікові } \\
\text { ЕС на } \\
\text { газі }\end{array}$ \\
\hline Потужність & $\mathrm{MBT}$ & 150 & 100 & 2200 & 600 & $240-50$ \\
\hline $\begin{array}{l}\text { Капітальні } \\
\text { витрати }\end{array}$ & $\$ / \mathrm{kBT}$ & $1100-1500$ & $1100-900$ & $\begin{array}{l}6900- \\
12200\end{array}$ & $\begin{array}{l}3000- \\
6250\end{array}$ & $700-950$ \\
\hline $\begin{array}{l}\text { Фіксовані } \\
\text { експлуатаційні } \\
\text { витрати }\end{array}$ & $\begin{array}{l}\$ / \mathrm{kBT} \\
\text { в рік }\end{array}$ & $\begin{array}{c}28.00- \\
36.50\end{array}$ & $\begin{array}{c}12.00- \\
9.00\end{array}$ & $\begin{array}{c}108.50- \\
133.00\end{array}$ & $\begin{array}{l}40.75- \\
81.75\end{array}$ & $\begin{array}{l}5.50- \\
20.75\end{array}$ \\
\hline $\begin{array}{l}\text { Змінні } \\
\text { експлуатаційні } \\
\text { витрати }\end{array}$ & \$/MВт·год & 一 & - & $3.50-4.25$ & $2.75-5.00$ & $4.75-6.25$ \\
\hline КВВП & $\%$ & $55-38$ & $34-23$ & $91-90$ & $83-66$ & 10 \\
\hline Ціна палива & \$/MMBtu & - & - & 0.85 & 1.45 & 3.45 \\
\hline Будівельний лаг & Місяців & 12 & 9 & 69 & $60-66$ & $12-18$ \\
\hline $\begin{array}{l}\text { Термін реалізації } \\
\text { проекту }\end{array}$ & Років & 20 & 30 & 40 & 40 & 20 \\
\hline $\mathrm{LCOE}$ & \$/МВт'год & $28-54$ & $32-42$ & $118-192$ & $66-152$ & $150-199$ \\
\hline
\end{tabular}

3 табл. 3 видно, що найменші витрати на виробництво електроенергії у ВЕС та СЕС, що збільшує економічні переваги відновлюваної енергетики над традиційними технологіями виробництва електроенергії.

Системний підхід до розвитку електроенергетики України. Функціонування потужного об'єкту електроенергетики (електростанції) супроводжується втручанням в функціонування складних систем, а саме:
1) Геологічної системи, поклади енергетичних корисних копалин якої використовуються в процесі перетворювання теплової або ядерної енергії в електроенергію на електростанціях традиційного типу.

2) Локального довкілля на територіях, прилеглих до електростанції.

3) Глобального (планетарного) довкілля. 
4) Системи розподілу i передачі електроенергії споживачам по лініям електропередачі.

5) Економічної системи, до якої входять:

- кредитна система,

- тарифна система,

- валютна система,

- інвестиційна система.

6) Політичної системи країн видобування і транзиту енергоносіїв.

Будь-яка технологія виробництва електроенергії зіштовхується 3 певними проблемами, що виникають внаслідок зазначених утручань.

Тому, розвиток електроенергетики має реалізовуватись в рамках системного підходу до проблеми і виходити з необхідності:

1) Мінімізації негативних наслідків зазначених утручань.

2) Урахування обмежень, що випливають з:

- поставлених цілей розвитку;

- наявного і перспективного розміщення виробничих сил країни з урахуванням анексії Криму і окупації Донбасу;
- соціального стану регіонів;

- особливостей технології генерування електроенергії;

- технічних можливостей задіяного енергетичного обладнання.

I хоч вже сьогодні відновлювана енергетика має суттєві переваги над традиційною, особливості української електроенергетики перешкоджають їй перейти до електроенергетики низьковуглецевої так швидко і легко, як це сталося для ряду країн Європи. Тому, для забезпечення зростаючого споживання електроенергії, потужності електростанцій традиційного типу має бути збережено в один із способів:

- модернізація обладнання;

- реновація обладнання зі збереженням традиційної технології;

- заміщення на обладнання для електростанцій на базі ВДЕ.

Природно, що має відбуватись реструктуризація електроенергетики України. Оптимізація іiі нової структури являє собою складну проблему (табл. 4-6).

Таблиця 4. Результати системного аналізу і рекомендації щодо розвитку ТЕС на газі.

Table 4. Results of system analysis and recommendations for the development of gas-fired thermal power plants.

\begin{tabular}{|c|c|c|c|c|}
\hline \multirow[t]{2}{*}{ № } & \multirow[t]{2}{*}{ Система } & \multicolumn{2}{|c|}{ Вплив ТЕС на газі на систему } & \multirow[t]{2}{*}{ Заходи } \\
\hline & & Негативний & Позитивний & \\
\hline 1 & $\begin{array}{l}\text { Геологічна - корисні } \\
\text { копалини }\end{array}$ & $\begin{array}{l}\text { Виснаження світових } \\
\text { покладів газу }\end{array}$ & - & $\begin{array}{l}\text { Розвідка і експлуатація } \\
\text { нових родовищ газу в } \\
\text { Україні }\end{array}$ \\
\hline 2 & $\begin{array}{l}\text { Локальне довкілля } \\
\text { (прилегле до } \\
\text { електростанції) }\end{array}$ & $\begin{array}{l}\text { Викиди в атмосферу речо- } \\
\text { вин, шкідливих для довкілля } \\
\text { і для здоров'я людей }\end{array}$ & - & $\begin{array}{l}\text { Застосування сучасних } \\
\text { технологій спалювання газу }\end{array}$ \\
\hline 3 & $\begin{array}{l}\text { Глобальне (планетарне) } \\
\text { довкілля }\end{array}$ & $\begin{array}{l}\text { Викиди парникових газів, що } \\
\text { сприяють зміні клімату на } \\
\text { планеті }\end{array}$ & - & $\begin{array}{l}\text { Застосування технологій } \\
\text { захвату парникових газів }\end{array}$ \\
\hline 4 & $\begin{array}{l}\text { Система розподілу і } \\
\text { передачі електроенергії } \\
\text { споживачам по лініям } \\
\text { електропередачі } \\
\end{array}$ & ( & $\begin{array}{lr}\text { Забезпечує } & \text { можливість } \\
\text { маневру } & \text { енергетичною } \\
\text { потужністю, } & \text { необхідного } \\
\text { для функціонування ОЕСУ }\end{array}$ & - \\
\hline 5 & Економічна система & $\begin{array}{l}\text { Тенденція стабільного } \\
\text { зростання ціни газу. } \\
\text { Валютна оплата імпортного } \\
\text { газу }\end{array}$ & (2) & $\begin{array}{l}\text { Диверсифікація } \\
\text { постачальників газу }\end{array}$ \\
\hline 6 & Iнше & $\begin{array}{l}\text { Ризики перебоїв в постачанні } \\
\text { газу через використання } \\
\text { політичної складової його } \\
\text { російськими } \\
\text { постачальниками }\end{array}$ & - & $\begin{array}{ll}\text { Часткове } & \text { заміщення } \\
\text { електроенергією з ВДЕ }\end{array}$ \\
\hline
\end{tabular}


Таблиця 5. Результати системного аналізу і рекомендації щодо розвитку ТЕС на вугіллі.

Table 5. Results of system analysis and recommendations for the development of coal-fired power plants.

\begin{tabular}{|c|c|c|c|c|}
\hline \multirow[t]{2}{*}{ № } & \multirow[t]{2}{*}{ Система } & \multicolumn{2}{|c|}{ Вплив ТЕС на вугіллі на систему } & \multirow[t]{2}{*}{ Заходи } \\
\hline & & Негативний & Познтивний & \\
\hline 1 & $\begin{array}{l}\text { Геологічна }- \text { корисні } \\
\text { копалини }\end{array}$ & $\begin{array}{l}\text { Складне видобування через } \\
\text { велику глибину залягання } \\
\text { пластів. Низька енергетична } \\
\text { якість через тонкі пласти і } \\
\text { суміш вугілля з породою }\end{array}$ & - & $\begin{array}{lr}\text { Застосування } & \text { сучасних } \\
\text { технологій } & \text { збагачення } \\
\text { вугілля } & \end{array}$ \\
\hline 2 & $\begin{array}{lr}\text { Локальне } & \text { довкілля } \\
\text { (прилегле } & \text { до } \\
\text { електростанціі) } & \end{array}$ & $\begin{array}{l}\text { Високий рівень викидів в } \\
\text { довкілля речовин, шкідливих } \\
\text { для флори, фауни і здоров'я } \\
\text { людей }\end{array}$ & - & $\begin{array}{lr}\text { Застосування } & \text { сучасних } \\
\text { технологій } & \text { спалювання } \\
\text { вугілля } & \end{array}$ \\
\hline 3 & $\begin{array}{l}\text { Глобальне (планетарне) } \\
\text { довкілля }\end{array}$ & $\begin{array}{l}\text { Найвищий рівень викидів } \\
\text { парникових газів }\end{array}$ & - & $\begin{array}{l}\text { Застосування технологій } \\
\text { захвату парникових газів }\end{array}$ \\
\hline 4 & $\begin{array}{l}\text { Система розподі.ту i } \\
\text { передачі електроенергіi } \\
\text { споживачам по лініям } \\
\text { електропередачі }\end{array}$ & 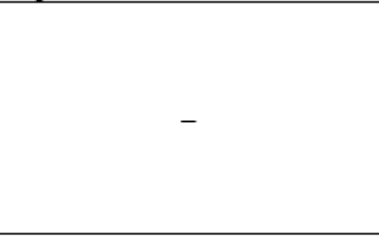 & $\begin{array}{lr}\text { Забезпечує частину базового } \\
\text { навантаження. } \\
\text { Частково } \\
\text { можливість } \\
\text { енергетичною } \\
\text { необхідного погпечує } \\
\text { функціонування ОЕСу } \\
\text { поневру } \\
\end{array}$ & 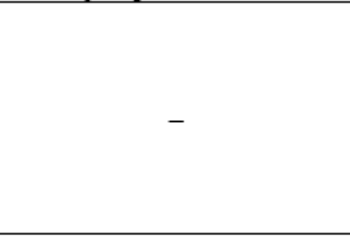 \\
\hline 5 & Економічна система & $\begin{array}{l}\text { Валютна оплата імпортного } \\
\text { вугілля }\end{array}$ & ( & - \\
\hline 6 & Iнше & 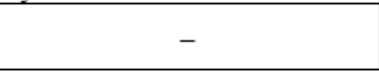 & - & $\begin{array}{ll}\text { Часткове } & \text { заміщення } \\
\text { електроенергією } 3 \text { ВДЕ }\end{array}$ \\
\hline
\end{tabular}

Таблиця 6. Результати системного аналізу і рекомендації щодо розвитку АЕС.

Table 6. Results of system analysis and recommendations for NPP development.

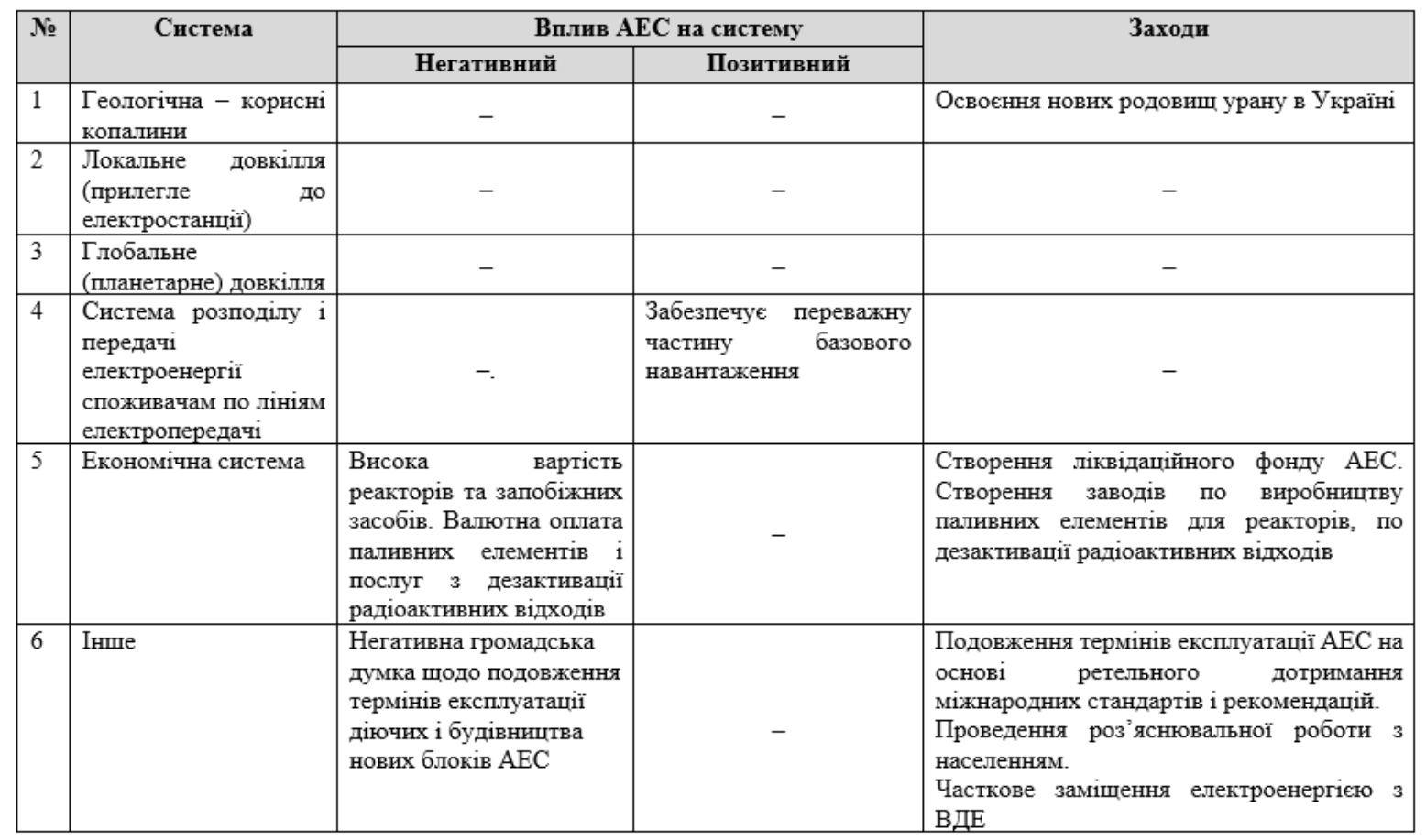

\section{Антикризова}

електроенергетики. Досвід Свропи. Кінець XX-го - початок XXI ст. ознаменувався тенденціями в електроенергетиці, що дали підставу аналітикам констатувати настання в Європі глибокої кризи електроенергетики.

Основні 3 зазначених тенденцій, що іiі спричинили, є такі: 
- picт і збільшення невизначеності прогнозних цін на енергоносії;

- збільшення впливу політичної складової у вирішенні енергетичних питань;

- значне посилення екологічних нормативів щодо викидів речовин, шкідливих для здоров’я людей і для довкілля;

- підписання переважною більшістю країн світу ряду міжнародних угод щодо переходу до сталої низьковуглецевої енергетики 3 метою запобігання зміні клімату на планеті;

- значне зростання питомих інвестицій в TEC i AEC через посилення вимог до його експлуатаційних i екологічних параметрів, a також через значне зменшення попиту на обладнання TEC і AEC;

- різка негативна думка населення Європи щодо доцільності розвитку атомної енергетики після глобальних катастроф на Чорнобильській AEC (1986 р.) i AEC Фукусіма-1 (2011р.);
- вичерпність можливості будівництва ГЕС на великих ріках Європи;

- невідповідність працюючих надпотужних електростанцій запровадженому в країнах ЄC внутрішньополітичному курсу на регіоналізацію економіки.

Перед європейськими країнами постала проблема пошуку нових шляхів виходу 3 енергетичної кризи, які б обходили перелічені перешкоди розвитку галузі. Оптимальним шляхом виходу 3 цієї кризи, який вирішує перелічені проблеми, в Європі було визнано стимулювання розвитку відновлюваної енергетики. Тому цій галузі було надано державну підтримку, яка сприяла напрацюванню технології масового виробництва високотехнологічного обладнання електростанцій на базі ВДЕ.

Така ж сама ситуація $з$ енергоносіями для AEC (рис. 11).

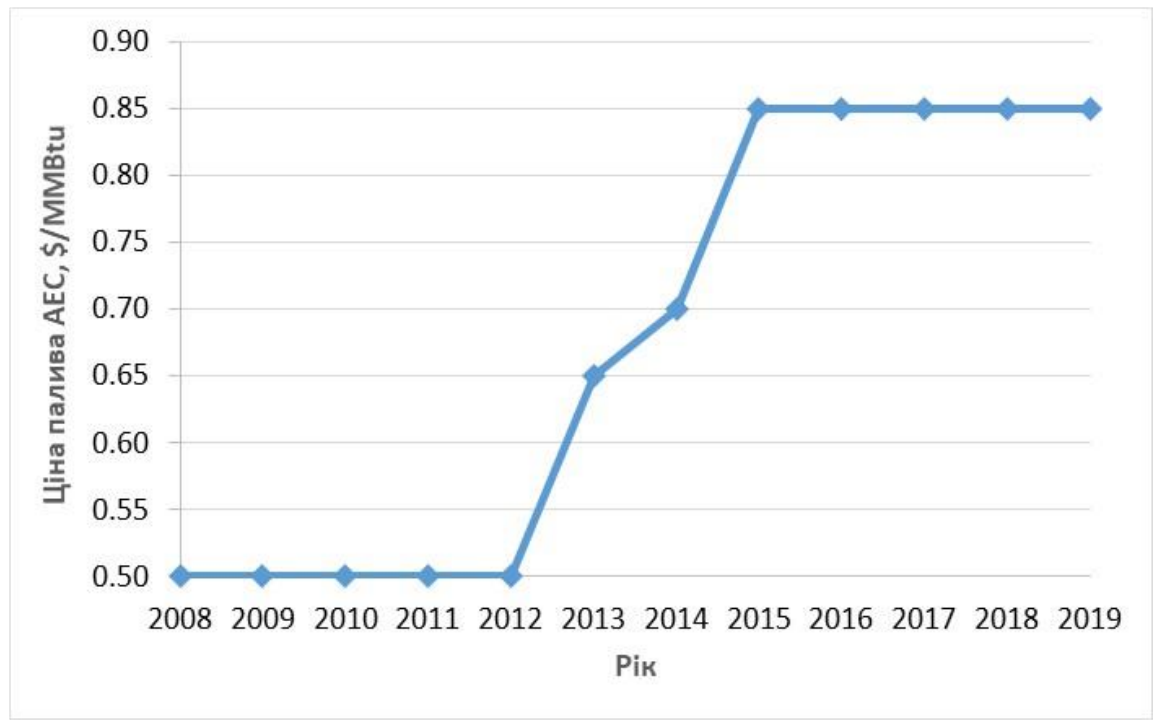

Рис. 11. Динаміка ціни на енергоносії AEC в CША за даними LAZARD'S [14].

Fig. 11. Dynamics of the price of NPP energy in the USA according to LAZARD'S [14].

32012 р. по 2019 р. ціна енергоносіїв для АЕС в Свропі зросла в 1.7 рази.

Ріст цін на енергоносії для АЕС $є$ наслідком об'єктивних причин - обмеженості і невідновлюваності їх запасів в природі. Крім того, через підвищення екологічних вимог до ТЕС і вимог щодо запобігання терактам i природним катаклізмам для АEC, суттєво зростають ціни на обладнання електростанцій традиційного типу. Тому, не може бути зупинений й ріст собівартості електроенергії, виробленої на ТЕС і АЕС.
Директива 2009/28/ЄС від 23.04.2009 в пункті №26 рекомендує наступне: "Бажано, щоб ціни на енергоносії відображали екстернальні витрати виробництва і споживання енергії, в тому числі, у відповідних випадках, екологічні, соціальні та витрати на охорону здоров'я".

Екстернальні витрати $є$ показниками, що дозволяють порівняти різного характеру загрози і шкідливості життю і здоров'ю людей від функціонування енергетичних технологій. Дані щодо екстернальних витрат в електроенергетиці подано в табл. 7. 
Таблиця 7. Питомі екстернальні витрати на виробництво електроенергії в країнах СС за даними [15].

Table 7. Specific external costs of electricity generation in EU countries according to [15].

\begin{tabular}{|l|r|}
\hline \multicolumn{1}{|c|}{ Тип електростанції } & $\begin{array}{c}\text { Екстернальні витрати, } \\
\text { єс/кВт·год }\end{array}$ \\
\hline TЕС на вугіллі & 18.75 \\
\hline AEC & 9.53 \\
\hline ГЕC & 4.50 \\
\hline BEC & 0.41 \\
\hline CEC & 1.12 \\
\hline БіоЕC & 6.62 \\
\hline
\end{tabular}

3 табл. 7 видно, що найбільші екстернальні витрати супроводжують виробництво електроенергії ТЕС, найменші - BEC. Ïх урахування в процесі розрахунку собівартості електроенергії збільшує економічні переваги відновлюваної енергетики над традиційними технологіями виробництва електроенергії.

Ще одну суттєву складову собівартості електроенергії теплових електростанцій почали обчислювати i враховувати після того, як 190 країн світу підписали Паризьку кліматичну угоду. Аналітики визначили, що для виконання своїх зобов'язань щодо запобігання зміни клімату, країни мають вводити плату за викиди за тарифом

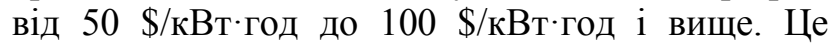
призведе до суттєвого підвищення собівартості електроенергії, виробленої на ТЕС [16].
Отже, проведений порівняльний аналіз засвідчує, що відновлювана енергетика має такі переваги над традиційною енергетикою:

- має найнижчу собівартість виробництва електроенергії;

- потребує мінімуму екстернальних витрат протягом реалізації повного технологічного циклу;

- використовує безпаливну технологію, що, крім економічних, має інші переваги: політичні, екологічні, валютні;

- має безвуглецеву технологію виробництва електроенергії, яка не сприяє зміні клімату.

Все це разом спричинило різке збільшення темпів росту встановленої потужності вітрових і сонячних електростанцій на тлі падіння потужності введених електростанцій традиційних типів (рис. 12).

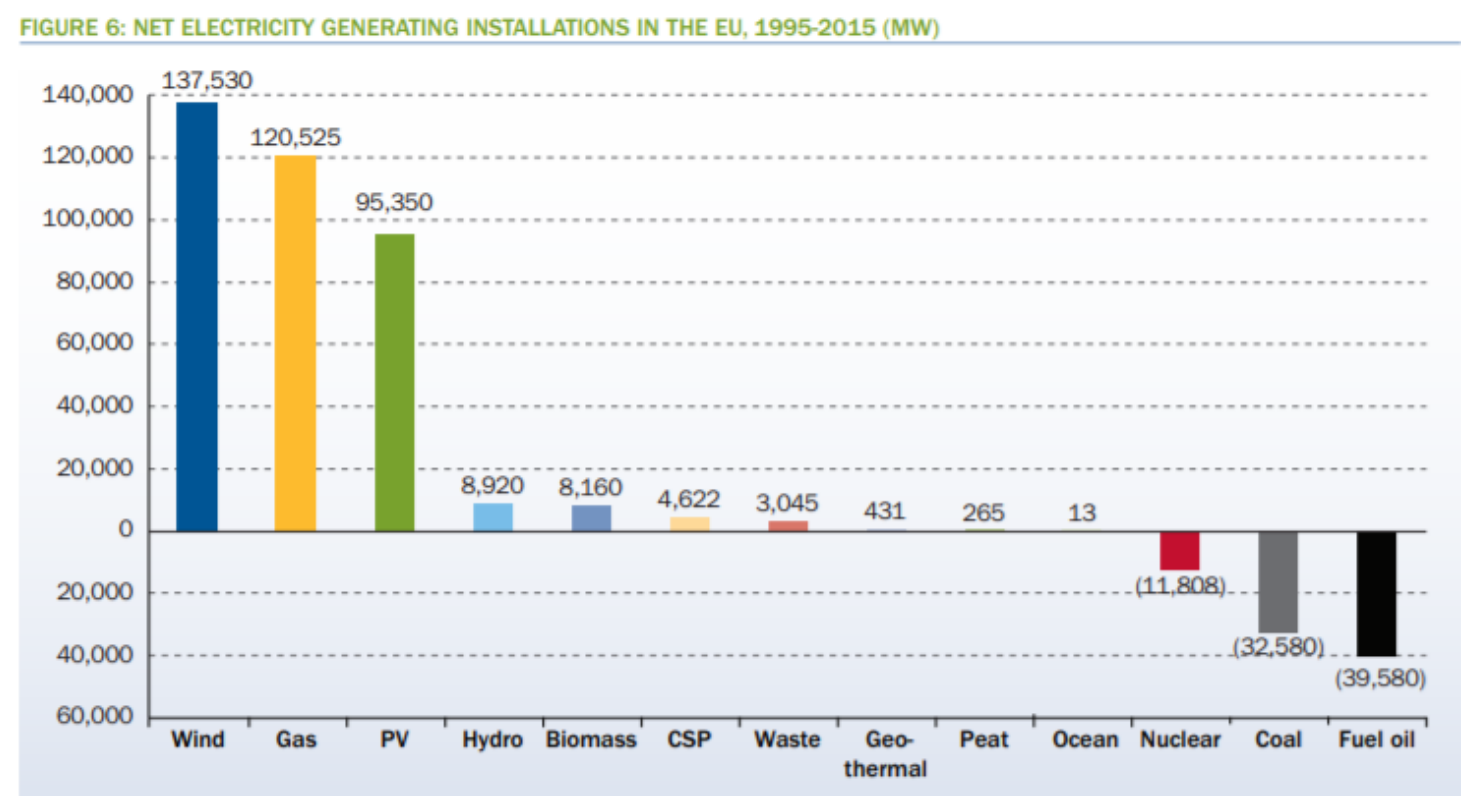

Рис. 12. Сальдо вводу-виводу електростанцій в Євросоюзі за період 1995-2015pp. [17].

Fig. 12. Balance of input-output of power plants in the European Union for the period 1995-2015 [17]. 
Аналіз рис. 12 засвідчує, що 3 традиційних галузей електроенергетики $\mathrm{CC}$ за відповідні 20 років розвиток отримали лише ТЕС, що працюють на газі. Ця технологія виробництва електроенергії дійсно $€$ ефективною з точки зору:

- електроенергетики - дозволяє здійснювати маневрування потужності;

- екології - суттєво менші глобальні і локальні викиди шкідливих речовин, ніж у ТЕС, що працюють на вугіллі;

- економіки - середня собівартість електроенергії нижча, ніж у ТЕС на вугіллі.

Але попри всі перелічені переваги, в останні роки газова електроенергетика перестала приваблювати європейських інвесторів (табл. 8). Причини цьому:

- дефіцит в країнах $\mathrm{CC} \mathrm{власних} \mathrm{покладів}$ газу;

- застосування країнами-постачальниками газу в Свропу (а це, в основному, Росія) даного енергоносія в якості засобу вирішення своїх політичних задач.

Підвищення дохідності інвестиційних проектів у відновлюваній енергетиці і зменшення ризиків призвело до різкого росту інвестицій в цю галузь (табл. 8).

Таблиця 8. Прогноз інвестицій в електроенергетику Свропейського Союзу за даними [18]. Низьковуглецевий сценарій.

Table 8. Forecast of investments in electricity of the European Union according to [18]. Low carbon scenario.

\begin{tabular}{|l|c|}
\hline Технологія виробництва електроенергії & Суми інвестицій, \$млрд. \\
\hline Традиційна & $2014-2035 \mathrm{pp}$. \\
\hline ТЕС на вугіллі & $\mathbf{4 0 0}$ \\
\hline TЕС на газі & 76 \\
\hline AЕС & 82 \\
\hline & 242 \\
\hline Відновлювана (вітер + сонце) & $\mathbf{1 3 5 8}$ \\
\hline
\end{tabular}

3 табл. 8 видно, що в період 2014-2035 рр. інвестиції у відновлювані технології виробництва електроенергії в країнах $\mathrm{CC}$ перевищать інвестиції в галузі традиційної енергетики (ТЕС і AEC) разом взяті, більше ніж у три рази.

Таким чином, результати функціонування європейської електроенергетики за новим “низьковуглецевим" курсом засвідчують, що стратегічні рішення в європейській електроенергетиці були вдалими - країни Свропи подолали всі перешкоди розвитку, перелічені на початку даного пункту. Зважаючи на подібність багатьох нагальних проблем української i європейської електроенергетики, а також на значний енергетичний потенціал відновлюваних джерел енергії України, зокрема енергії сонця та вітру — 2273 млрд кВт·год у рік [19], стратегічні рішення для української електроенергетики мають враховувати відповідний європейський досвід.

Проведений вище аналіз дає обгрунтований висновок, що відновлювані технології виробництва електроенергії найбільш привабливі для інвесторів.

\section{Висновки.}

1. У другій половині $\mathrm{XX}$ ст. електроенергетика більшості країн світу (а в Європі - практично всіх країн) отримала серйозні виклики. Зношеність енергетичного обладнання TEC i AEC перевищила допустимі проектні ліміти, що зменшило стійкість постачання електроенергії споживачам, збільшило обсяги локальних i глобальних шкідливих викидів, збільшило питомі витрати палива на TEC і AEC, a 3 цим - збільшило собівартість і ціну продажу електроенергії. Другим викликом для електроенергетики Європи стала залежність від імпорту палива.

2. Щодо української електроенергетики, то вона отримала у відповідний період і по даний момент такі самі проблеми, що й Свропа. Але, на даний момент в Європі всі ці проблеми подолано, i для України є дуже важливим цей позитивний досвід подолання кризи в електроенергетиці.

3. Європейські країни обрали пріоритетний розвиток виробництва електроенергії 3 відновлюваних джерел енергії, що дозволило подолати всі перелічені вище проблеми енергетичного обладнання, енергоносіїв, екології і економіки. 
4. Інвестиції у відновлювані технології виробництва електроенергії в країнах $Є \mathrm{C}$ до 2035 p. перевищать інвестиції в галузі традиційної енергетики (ТЕC і AЕC) разом взяті, більше ніж у три рази.

1. Річний звіт. 2016. 22 с. [Електронний ресурс]. URL: https://ua.energy/wp-content/uploads/2018/02/Annualreport_2016.pdf.

2. Да будет свет: где и сколько электроэнергии потребляют и производят в Украине. [Електронний ресурс]. URL: https://businessviews.com.ua/ru/studies/id/da-budet-svetgde-i-skolko-elektroenergii-potrebljajut-v-ukraine-1166/.

3. Встановлена потужність енергосистеми України. [Електронний pecypc]. URL: https://ua.energy/vstanovlenapotuzhnist-energosystemy-ukrayiny/.

4. Звіт 3 оцінки відповідності (достатності) генеруючих потужностей. Укренерго. 2017. 117 c. [Електронний pecypc]. URL: https://ua.energy/wpcontent/uploads/2017/10/Zvit-z-otsinky-vidpovidnostidostatnosti-generuyuchyh-potuzhnostej.pdf .

5. Вольчин І.А., Дунаєвська Н.І., Гапонич Л.С. та ін. Перспективи впровадження чистих вугільних технологій в енергетику України. К. Гносіз. 2013. 308 с.

6. Экологическая экспертиза. информация. Выпуск № 4. ВИНИТИ. 2015. [Електронний ресурc]. URL: http://lamb.viniti.ru/sid2/sid2free?sid2=J13583597 .

7. Барановський B.A. та ін. Україна. Екологогеографічний атлас. Рада по вивченню продуктивних сил України. К. Варта. 2006. Карта 4.4.5.

8. Кудря С.О., Тучинський Б.Г., Іванченко І.В. Вітроенергетика України - цілі, зобов'язання, результати і перспективи. Відновлювана енергетика та енергоефективність у XXI столітті. Матеріали XX міжнародної науковопрактичної конференції. Київ. 2019. С. 408-414.

9. Comparison of Lifecycle Greenhouse Gas Emissions of Various Electricity Generation Sources. WNA Report. 2011. [Електронний ресурс]. URL:

http://worldnuclear.org/uploadedFiles/org/WNA/Publications/W orking_Group_Reports/comparison_of_lifecycle.pdf .

10. Безруких П.П. Ветроэнергетика. Справочное и методическое пособие. М. ИД «Энергия». 2010. С. 159-160.

11. Миронов В.П., Журавков В.В. Обращение с радиоактивными отходами. Минск. МГЭУ им. А.Д. Сахарова. 2009. 27 с.

12. Томас C. Экономика ядерной енергетики Публикация, посвященная ядерным проблемам. Heinrich Böll Foundation. 2005. №. 5. С. 35-36. [Електронний ресурс].

URL: https://www.boell.de/sites/default/files/assets/boell.de/ima ges/download_de/oekologie/ru_05_Thomas.pdf.

13. Lazards levelized cost of energy analysis. Version 13.0. 2019. Pp. 16-18. [Електронний ресурс].

URL: https://www.lazard.com/media/451086/lazards-levelizedcost-of-energy-version-130-vf.pdf .

14. Lazards Levelized Cost of Energy Analysis. Version 2.0-13.0. 2008-2019. [Електронний ресурс]. URL: https://www.lazard.com/.

15. Burtraw D., Krupnick A., Sampson G. The True Cost of Electric Power. Resources For the Foture. Washington. REN21. 2012. 48 p.

16. Пэрри Иэн. Страны принимают обязательства взимать высокую плату за выбросы углерода. 2016. [Електронний ресурc]. URL:

http://www.imf.org/external/russian/np/blog/2016/042116r.pdf .

17. Wind in Power. 2015. European Statistics. EWEA. 8. p. [Електронний ресурс]. URL: https://windeurope.org/wp-
content/uploads/files/about-wind/statistics/EWEA-AnnualStatistics-2015.pdf.

18. World Energy Investment Out Look. OECD/IEA. 2014. 167 p. [Електронний ресурc]. URL: https://www.ourener gypolicy.org/wp-content/uploads/2014/06/WEIO2014.pdf .

19. Атлас енергетичного потенціалу відновлюваних джерел енергії України. За заг. ред. С.О. Кудрі. Київ. Інститут відновлюваної енергетики НАН України. 2020. 82 с.

\section{REFERENCES}

1. Richnyy zvit. [Annual report]. 2016. 22 p. [Electronic resource]. URL: https://ua.energy/wpcontent/uploads/2018/02/Annual-report_2016.pdf .

2. Da budet svet: gde i skolko elektroenergii potreblyayut i proizvodyat $\mathrm{v}$ Ukraine. [Let there be light: where and how much electricity is consumed and produced in Ukraine] [Electronic resource]. URL: https://businessviews.com.ua/ru/stu dies/id/da-budet-svet-gde-i-skolko-elektroenergii-potrebljajut-vukraine-1166/.

3. Vstanovlena potuzhnist enerhosystemy Ukrayiny. [The capacity of the power system of Ukraine is installed]. [Electronic resource]. URL: https://ua.energy/vstanovlenapotuzhnist-energosystemy-ukrayiny/ . [in Ukrainian].

4. Zvit $\mathrm{z}$ otsinky vidpovidnosti (dostatnosti) heneruyuchykh potuzhnostey. [Report on conformity assessment (sufficiency) of generating capacities]. Ukrenerho. 2017. 117 p. [Electronic resource]. URL: https://ua.energy/wpcontent/uploads /2017/10/Zvit-z-otsinky-vidpovidnosti-dostatnostigeneruyuchyhpotuzhnostej.pdf. [in Ukrainian].

5. Volchyn I.A., Dunayevska N.I., Haponych L.S. ta in. Perspektyvy vprovadzhennya chystykh vuhil'nykh tekhnolohiy v enerhetyku Ukrayiny. [Prospects for the introduction of clean coal technologies in the energy sector of Ukraine]. K. Hnosiz. 2013. 308 p. [in Ukrainian].

6. Ekologicheskaya ekspertiza. Obzornaya informaciya. [Ecological examination. Overview information.]. VINITI. 2015. Issue No. 4. 27 p. [Electronic resource]. URL:

http://lamb.viniti.ru/sid2/sid2free?sid2=J13583597. [in Russian].

7. Baranovskyy V. A. ta in. Ukrayina. Ekolohoheohrafichnyy atlas. Rada po vyvchennyu produktyvnykh syl Ukrayiny. [Ukraine. Ecological and geographical atlas. Council for the Study of the Productive Forces of Ukraine]. K. Varta. 2006. Karta 4.4.5. [in Ukrainian].

8. Kudria S.O., Tuchynskyi B.H., Ivanchenko I.V. Vitroenerhetyka Ukrayiny - tsili, zobovyazannya, rezultaty i perspektyvy. [Wind energy Ukraine - aims, liabilities, results and prospects]. Vidnovlyuvana enerhetyka ta enerhoefektyvnist $u$ XXI stolitti. Materialy XX mizhnarodnoyi naukovo-praktychnoyi konferentsiyi. K. 2019. Pp. 408-414. [in Ukrainian].

9. Comparison of Lifecycle Greenhouse Gas Emissions of Various Electricity Generation Sources. WNA Report. 2011. [Electronic resource]. URL: http://worldnuclear.org/uploadedFil es/org/WNA/Publications/Working_Group_Reports/comparison _of_lifecycle.pdf. [in English].

10. Bezrukih P.P. Vetroenergetika. Spravochnoe i metodicheskoe posobie. [Wind energy. Reference and methodical manual]. M. ID «Energiya». 2010. Pp. 159-160. [in Russian].

11. Mironov V.P., Zhuravkov V.V. Obrashchenie s radioaktivnymi othodami. [Radioactive waste management]. Minsk. MGEU im. A.D. Saharova. 2009. 27 p. [in Russian].

12. Tomas S. Ekonomika yadernoj energetiki. Publikaciya, posvyashchennaya yadernym problemam. [Economics of nuclear energy. Publication on Nuclear Problems]. Heinrich Boll Foundation. 2005. No. 5. Pp. 35-36. [Electronic resource]. URL: https://www.boell.de/sites/default/files/assets/bo ell.de/images/download_de/oekologie/ru_05_Thomas.pdf. [in Russian]. 
13. Lazards levelized cost of energy analysis. Version 13.0. 2019. Pp. 16-18. [Electronic resource]. URL: https://www.lazard.com/media/451086/lazards-levelized-cost-ofenergy-version-130-vf.pdf . [in English].

14. Lazards Levelized Cost of Energy Analysis. Version 2.0-13.0. 2008-2019. [Electronic resource]. URL: https://www.lazard.com/. [in English].

15. Burtraw D., Krupnick A., Sampson G. The True Cost of Electric Power. Resources For the Foture. Washington. REN21. 2012. 48 p. [in English].

16. Perri Ien. Strany prinimayut obyazatel'stva vzimat' vysokuyu platu za vybrosy ugleroda. [Countries commit to charging high carbon emissions]. 2016. [Electronic resource]. URL: http://www.imf.org/external/russian/np/blog/2016/042116r .pdf . [in Russian].
17. Wind in Power. 2015 European Statistics. EWEA. P. 8. [Electronic resource]. URL: https://windeurope.org/wpcontent/uploads/files/about-wind/statistics/EWEA-AnnualStatistics-2015.pdf . [in English].

18. World Energy Investment Out Look. OECD/IEA. 2014. P. 167. [Electronic resource]. URL: https://www.ourenerg ypolicy.org/wp-content/uploads/2014/06/WEIO2014.pdf. [in English].

19. Atlas enerhetychnoho potentsialu vidnovlyuvanykh dzherel enerhiyi Ukrayiny. Za zah. red. S.O. Kudri. [Atlas of energy potential of renewable energy sources of Ukraine. For general. ed. S. Kudria]. Kyiv. Instytut vidnovlyuvanoyi enerhetyky NAN Ukrayiny. 2020. 82 p.

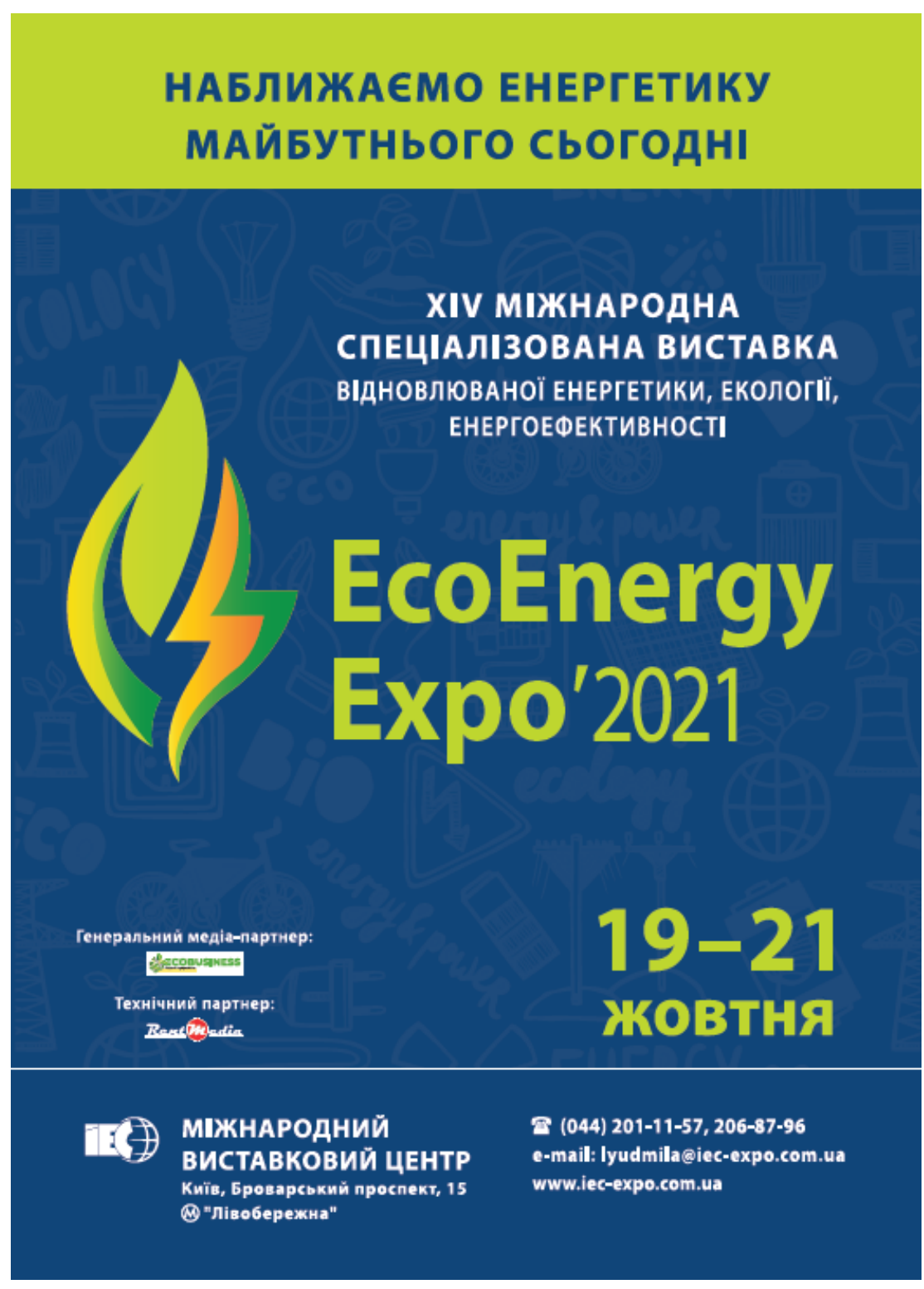

